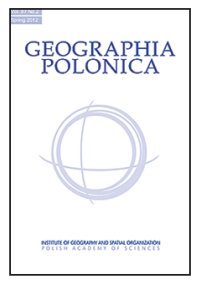

\title{
MONITORING OF CHANGES IN ROAD POTENTIAL ACCESSIBILITY AT MUNICIPALITY LEVEL IN POLAND, 1995-2015
}

\author{
Piotr Rosik - Marcin Stępniak \\ Institute of Geography and Spatial Organization \\ Polish Academy of Sciences \\ Twarda 51/55, 00-818 Warsaw: Poland \\ e-mails: rosik@twarda.pan.pl•stepniak@twarda.pan.pl
}

\begin{abstract}
The main objective of this article is to show the effects of changes in road accessibility in Poland at municipality level over the long term of 20 years (1995-2015). The methodological basis is the potential accessibility indicator. A multi-criterion analysis of accessibility dimensions has been prepared and the international level has been included, with destinations located across the whole European continent. One of the main conclusions is that, during the years 1995-2015, regional disparities to the level of accessibility increased. Improvements in accessibility were found to be distributed across the country unevenly, with regions located in central and southern Poland identified as the greatest beneficiaries. The results can be seen to represent scientific background for transport policy priorities in Poland.
\end{abstract}

\section{Key words}

potential accessibility roads $\cdot$ evaluation - Poland

\section{Introduction}

Accessibility is a widely-used term that plays an important role in many scientific fields (Spiekermann \& Neubauer 2002). A number of explanations and attempts to define the concept are to be found in the literature on transport geography. According to Hansen (1959), accessibility can be defined by "the potential of opportunities for interaction". Ingram (1971) treats accessibility as an "inherent characteristic (or advantage) of a place with respect to overcoming some form of spatially operating source of friction (for example, time and/or distance)". Vickerman (1974) emphasizes that accessibility "involves a combination of two elements: location on a surface relative to suitable destinations, and the characteristics of the transport network or networks linking points on the surface". Bruinsma and Rietveld (1998) agree that accessibility is the "attractiveness 
of a node in a network, taking into account the mass of other nodes and the costs to reach those nodes via the network".

The objective of the study is to analyse spatial accessibility within Poland using a model of potential as the research method. By including multiple dimensions of accessibility in a modelling study it is possible to carry out a dynamic evaluation of the effects of infrastructural projects in terms of change looked at either ex post or ex ante. In Poland, a country undergoing a breakthrough in its transport infrastructure, potential accessibility is an important measure for practical applications, and the evaluation of change in accessibility has emerged as one of the most important criteria by which to assess such projects.

The main objective of this article is to lay the foundations for a comprehensive methodology by which to monitor road accessibility at the municipality level in Poland, over the long term of 20 years (1995-2015). The methodological basis is the potential accessibility indicator (Komornicki et al. 2010; Rosik 2012; Stępniak \& Rosik 2013; Stępniak et al. 2013; Rosik et al. 2015), as based on the assumption that, when travel time increases, the attractiveness (herein represented by the population) of the destination is reduced. A multi-criterion analysis of accessibility dimensions has been prepared for the period 1995-2015. The international level has been taken into account, with destinations located across the whole European continent included. The methodology of analyses presented in this study follows the relatively new (and still not widely prevalent) path of papers including highly-detailed spatial resolution of municipalities at different spatial scales. Moreover, the main aim of the research is to fill a gap in our knowledge as regards the use of different accessibility dimensions, and motorway and express road investments; since the construction of new high-capacity roads is the most important factor influencing accessibility in Poland, irrespective of the level of analysis.

\section{Methodology}

There are different approaches to the methodology of measuring accessibility. On the basis of a literature survey (Geurs \& van Eck 2001), it is possible to identify five groups of method, i.e.:

- the infrastructure-based accessibility measure - using infrastructure development indicators for the area concerned, such as the quantity of infrastructure and its quality, as well as congestion;

- the distance-based accessibility measure (travel-cost accessibility) - i.e. accessibility measured by the physical, temporal or economic distance to a destination or set of destinations, e.g. the minimum, average or total cost of travel between the origin of the trip and other destinations;

- the isochronic-based accessibility measure (cumulative accessibility) - i.e. accessibility measured by determining a set of destinations accessible within a specific time period (or possibly at a specific cost or with a given travel effort), e.g. research using destination (population) accessibility isochrones within 15-, 30-, 45- or 60-minute time distances from the origin;

- the person-based accessibility measure - analysing accessibility at the individual level;

- the potential-based accessibility measure - the most popular method, which is also used in this paper.

Potential accessibility is measured by the number of activities (opportunities) reachable within a certain distance, time or cost. In other words the accessibility indicator is the sum of the mass of each other region divided by the shortest travel time to it. The closer the opportunity (mass of each other region), the more it contributes to accessibility. The greater the opportunity, the more it influences accessibility. The concept of potential accessibility was introduced by the social physics school, and devised by Hansen (1959). The history of the model of potential goes back to the 1950s, with researchers influencing 
the authors' understanding of the topic most including: Hansen (1959), Keeble et. al. (1982), Schürmann et. al. (1997), Schürmann and Talaat (2000), Geurs and van Eck (2001), Gutiérrez(2001), Spiekermann and Neubauer (2002), and Holl (2007).

In Poland, potential accessibility studies first developed in the 1960s. In his seminal work, Chojnicki (1966) provided theoretical foundations, as well as a discussion of the application of gravitation and potential models in spatial and economic research. Poznań is a city in which potential accessibility studies were cultivated, with a focus on the region's towns (Ratajczak 1999), as well as on the whole country (Czyż 2002). Elsewhere, potential accessibility has been an area visited only seldom by researchers, with the notable exceptions of Guzik (2003), Koźlak (2012) and Wiśniewski (2015). Despite a relatively early study by Potrykowski and Taylor (1982), and Taylor (1999) who introduced the theoretical foundations of gravitation and potential models at IGSO PAS, no comprehensive analysis of accessibility was available in Poland that would combine the theoretical and empirical aspects over the transition period. This may bring plausibility to a claim that the objective of this study is a relatively unoccupied niche in Polish research in the field.

Monitoring of road accessibility means a permanent, systematic study of changes in accessibility, in the context of cohesion and the reduction of interregional disparities. The use of the potential model allows for a dynamic approach to the phenomenon of accessibility (Holl 2007). An evaluation may be performed as a string of simulations concerning change of accessibility, both ex post and ex ante, for individual infrastructural projects (Stępniak \& Rosik 2013; Michniak et al. 2015) and for entire programmes (Więckowski et al. 2014; Rosik et al. 2015).

\section{Study area}

In Poland, post-1989, the decline in freight transport and the rapid increase in private mobility and motorisation (much faster than
GDP growth) resulted in people owning more than 450 motor vehicles per 1000 inhabitants as of 2010. In spite of this growing motorisation of society, the 1990s proved to be a decade of further delay with major decisions concerning investments in transport infrastructure investments. However, after 2000, Poland made up for lost time by implementing Europe's largest national motorway construction programme. While about $500 \mathrm{~km}$ of motorways and expressways were in operation in 2000, while 15 years later, in 2015, more than $3000 \mathrm{~km}$ was in operation, with another several hundred under construction.

In this paper the travel impedance is the shortest car-travel time between each pair of municipalities. This travel time was calculated by applying the method of identifying the shortest travel routes (Rosik 2012; Śleszyński 2015), in line with Dijkstra's algorithm. The shortest road-travel times were calculated using the travel speed model based on 14 pre-defined categories of road in Poland. The regulations of the Polish Highway Code are used as a point of departure, and travel speeds are then reduced, taking into account location within built-up areas, population density and topographic impediments (Rosik 2012; Śleszyński 2014). Travel times on roads outside Poland were estimated on the basis of road category and the highway regulations of the particular European countries (cf. Stępniak \& Rosik 2013; Rosik et al. 2015); for an extended description see Rosik (2012). The importance of separate settlement centres (at the LAU-2 - municipal level) is determined on the basis of municipal population. Potential accessibility is then described by the formula:

$$
A_{i}=P O P i f\left(t_{i}\right)+\sum_{j} P O P f\left(t_{j}\right)+\sum_{z} P O P_{z} f\left(t_{z}\right)
$$

where:

$A_{i} \quad$ - potential accessibility of municipality $i$,

$P O P_{i}$ - population of municipality $i$,

$P O P_{j}$ - population of municipality $j$,

$P O P_{z}$ - population of the transport zone $z$ located outside Poland,

$t_{i i}$ - internal car travel time within the municipality $i$, 
$t_{i j-}$ car travel time between municipalities $i$ and $j$,

$t_{i z}-$ car travel time between municipality $i$ and the transport zone $z$ located outside Poland.

The dimensions of potential accessibility analysed are as follows:

- accessibility components - analysis of changes in accessibility resulting, firstly, from the development of infrastructure (the network component which means the modernisation or construction of new sections) and, secondly, the consequence of population change (demographic component),

- trip length - analysis of changes in accessibility for road users travelling short and long distances through a differentiation of the distance decay parameters in the exponential function; it is possible to estimate the potential accessibility for different types of travel (e.g. short- and longdistance trips) by adopting different values for $\beta$ parameters in the exponential function $f(t)=\exp (-\beta t)$; we adopt two different $\beta$ parameters: 0.023105 for short trips and 0.005775 for long trips),

- presentation of phenomena - the analysis of both relative and absolute changes, as well as charts showing beta and sigma accessibility convergence/divergence,

- spatial scale - analysis of changes in accessibility at the national and international (European) level.

\section{Accessibility components}

Potential accessibility consists of two components: a land-use component, which describes the attractiveness of the destination (population, GDP, etc.), and a transport component, which provides information on how the attractiveness of the destination decreases with physical distance, travel time, cost or effort (Geurs \& van Eck 2001). The role of the demographic factor (land-use component) and infrastructure factor (transport component) varies depending on population change and investment in new infrastructure over a given period of time. The changes in potential accessibility that result from population changes should outline the demographic processes taking place in Poland in the years 1995-2015, i.e.:

- demographic slowdown, due to declining birth rates,

- migration outflow from peripheral areas and regions with traditional industries (Upper Silesia, Łódź),

- migration inflow to metropolitan areas in general, and to the Warsaw Metropolitan Area in particular,

- migration outflow abroad (after 2004),

- rapid suburbanisation process.

The suburbanisation processes and depopulation of large areas of the country have a direct impact in changing potential accessibility to the population. Assuming that there is no change in road infrastructure (infrastructure constant), the demographic changes lead to a $5 \%$ increase in accessibility in Kashubia and the Warsaw region. The area of increase in accessibility resulting from population growth takes the shape of an inverted $V$, with its apex in Pomerania and the edges reached in the northern part of Lubuskie Voivodeship, as well as central parts of the Mazowieckie (Mazovia) region. In addition, population growth in Małopolskie Voivodeship and the western part of Podkarpackie has a positive effect on accessibility in this part of the country. On the other hand, a decrease in potential accessibility due to demographic processes is visible along the Polish-Czech border, in Opolskie Voivodeship, Upper Silesia, and the eastern part of Lubelskie Voivodeship (Fig. 1).

Before 2000, the impact of demography on the road accessibility of the population was relatively greater due to the lack of major road projects (Rosik 2012). However, over the entire two decades, the infrastructure factor has proved much more significant than that involving demography, exerting a much greater impact in changing accessibility. Infrastructure development (assuming no demographic change) results in some cases in a near-doubling of potential accessibility (in particular in municipalities 


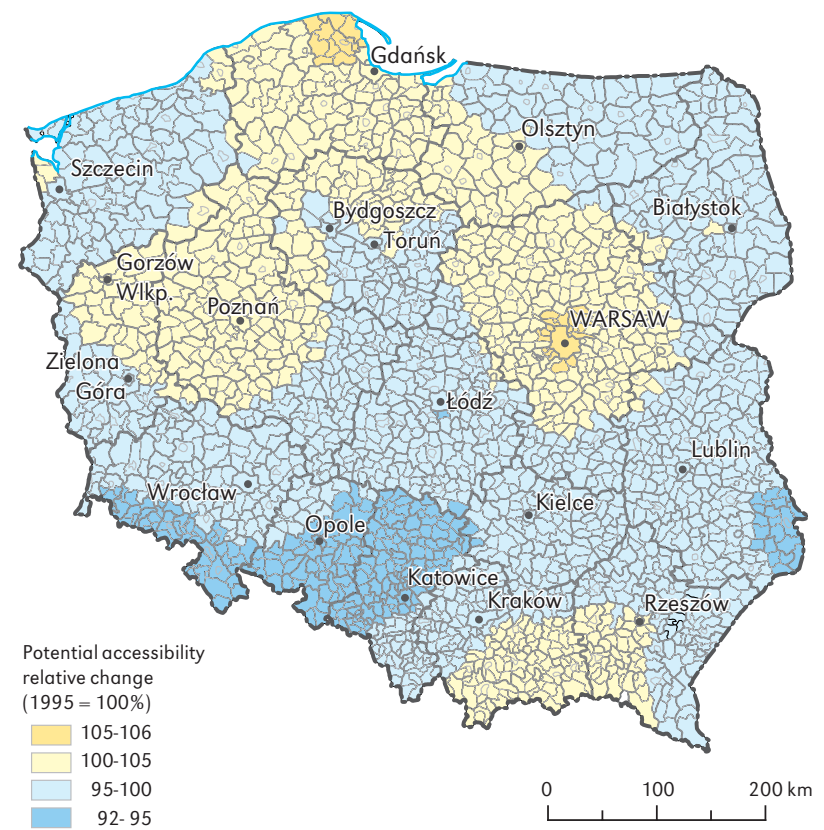

Figure 1. Demographic impact on potential road accessibility (1995-2015; relative changes - infrastructure constant; short trips)

located along the corridors of the A2 and A4 motorways and, to a lesser extent, along the A1 motorway). In contrast to the demographic factor, infrastructure's impact on accessibility change is always positive, as the development of infrastructure can only improve the level of accessibility (Fig. 2).

The study of the combined effect of both (demographic and infrastructure) factors (Fig. 3), when compared with the effects of the infrastructure factor (Fig. 2), shows that only in exceptional cases (like in Opole (Opolskie) Voivodeship) does the demographic factor decrease the effect of improvements in infrastructure.

Alongside motorways with their positive impact, there are also the express roads, in particular those built in the years 20102015, which also influence the spatial distribution to changes in accessibility. The improvement in accessibility is visible in those areas along motorway routes and the S8 expressway corridor from Wrocław through Piotrków Trybunalski towards Białystok. Positive effects are also observed along the northern section of the S3 expressway, along the completed sections of expressway S7, as well as on the western stretch of the border with the Kaliningrad Oblast (the effect of the S22 express road). The accessibility increase is very small (of less than 5\%) in the Middle Pomerania region, in the northern part of Lubelskie Voivodeship, and in the Masuria region (Fig. 3).

\section{Trip length}

The analysis presented so far shows the results of changes in accessibility for short trips. It is shown that destination attractiveness decreases rapidly, with destinations located far from the origin exerting little effect on the final accessibility results. However, this situation changes if long trips are taken account of. For this type of trip, destinations located further afield are still attractive for travel and have an impact on the final accessibility results.

If we consider the analysis of accessibility level, for longer trips the accessibility is highest 


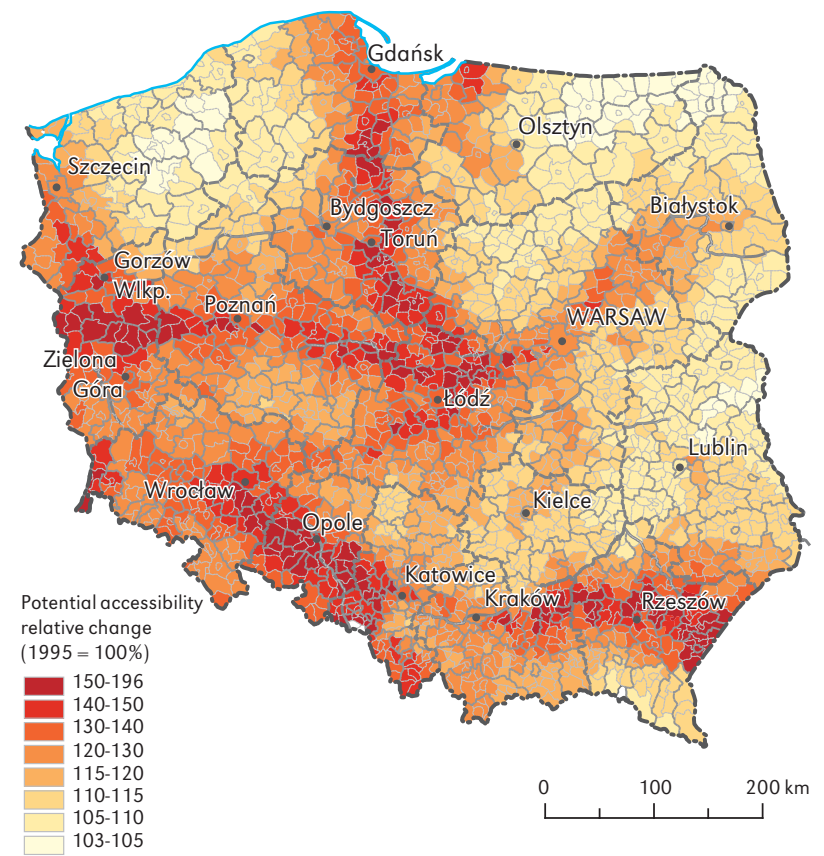

Figure 2. Infrastructure impact on potential road accessibility (1995-2015; relative changes - demography constant; short trips)

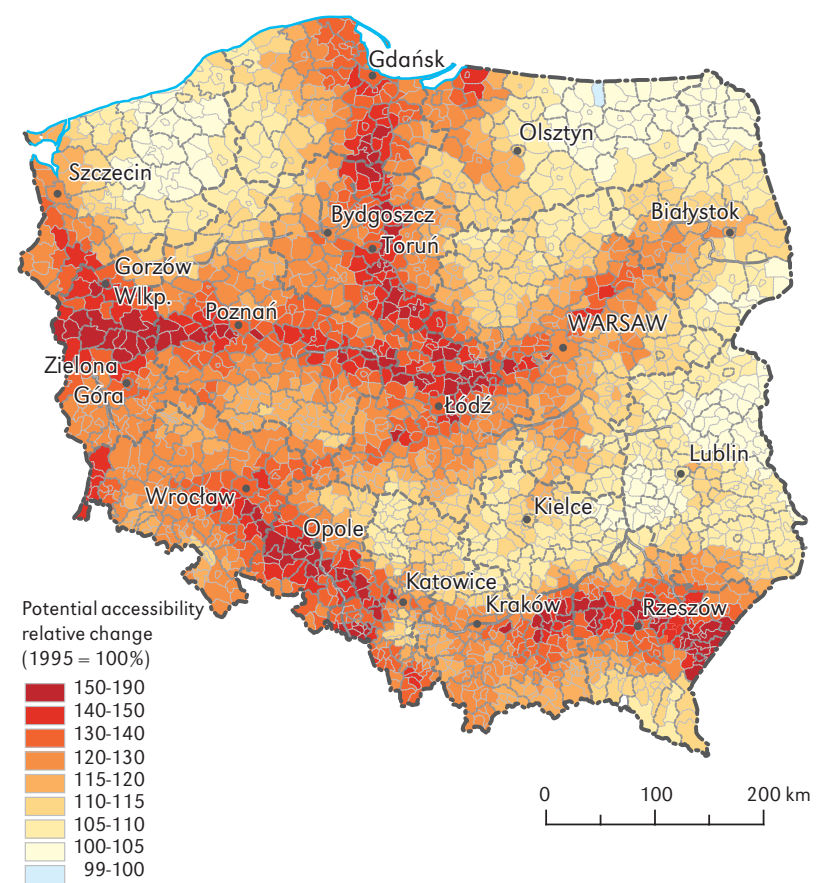

Figure 3. Potential road accessibility changes (1995-2015; relative terms; short trips) 
within the triangle between Konin, Warsaw and Katowice (Rosik 2012). This is a typical accessibility pattern for long trips, due to the fact that these stimulate the accessibility of those areas located in the centre of the area of study. If we consider the 1995-2015 period, the results of the study for long trips are significantly different from that for short trips (Fig. 4).

In the years 1995-2015, peripheral areas gained much more than central ones in comparison with the short-trip analysis. The positive effects are visible in particular in those border areas located around the near-border sections along the new motorways and expressways. This explains a significant improvement in accessibility visible in the Kashubia region (the effect of new opportunities for travel provided by the northern part of the A1 motorway), in Lubuskie Voivodeship, and in the western part of Zachodniopomorskie (the effect of the construction of the Polish-German near-border sections of the A2 motorway and the $\mathrm{S} 3$ expressway between that motorway and Szczecin). Positive effects are also visible in the near-border sections of the A4. The A2 Łódź-Warsaw section, the extension of the 88 express road and other investments in the Warsaw Metropolitan Region which are important for long trips create the 'accessibility increase fan' also observed in Podlaskie Voivodeship. The regions suffering from a lack of significant accessibility improvement are the Masuria region, as well as Lubelskie and Świętokrzyskie voivodeships.

\section{Presentation of the phenomenon}

The emphasis so far in this paper has been on the relative changes between the final and base state over the years 1995-2015. However, this is not the only way to present the results. An alternative possibility is to present them in the form of changes in absolute terms. Due to the potential model structure, relative changes in accessibility in peripheral areas are much greater than absolute ones because of the so-called low base effect. Areas with low baseline accessibility gain much more in percentage terms than those located centrally with a higher 'base'; while the absolute changes in accessibility level in the central regions are greater than in peripheral areas (especially when short trips are taken into account) (Fig. 5).

In absolute terms, the beneficiaries here are Łódzkie, Ślaskie and Opolskie voviodeships (i.e. the Łódź, Silesia and Opole regions) and to a lesser extent, Mazowieckie and Małopolskie. At the other extreme, the peripheral regions of Lubelskie, Podlaskie, Zachodniopomorskie and Warmińsko-Mazurskie are among those suffering from the lack of a sufficient increase in accessibility in absolute terms. In the case of three other peripheral regions, Lubuskie, Pomorskie and Podkarpackie, the presentation of the phenomenon (whether in relative or absolute terms) has a marked impact on the accessibility pattern. The changes in accessibility in relative terms in these provinces are among the largest in the country, while if one considers the changes in absolute terms - these regions are only in the middle of the ranking.

\section{Accessibility convergence or divergence}

The impact on cohesion is measured using the beta and sigma convergence procedure, which takes into account the standard deviation of potential accessibility values across municipalities. If less accessible regions, when compared with more accessible ones, are characterised by an increase in the level of accessibility greater than the national average, then accessibility beta convergence occurs. In the opposite case, accessibility divergence is deemed to have taken place. Regions which are catching up, winners and losers, are characterised in relation to the increase in national average accessibility, and the base level of road accessibility in 1995 (Fig. 6).

The 'winners' out of the investment process are Śląskie, Łódzkie, Mazowieckie and 


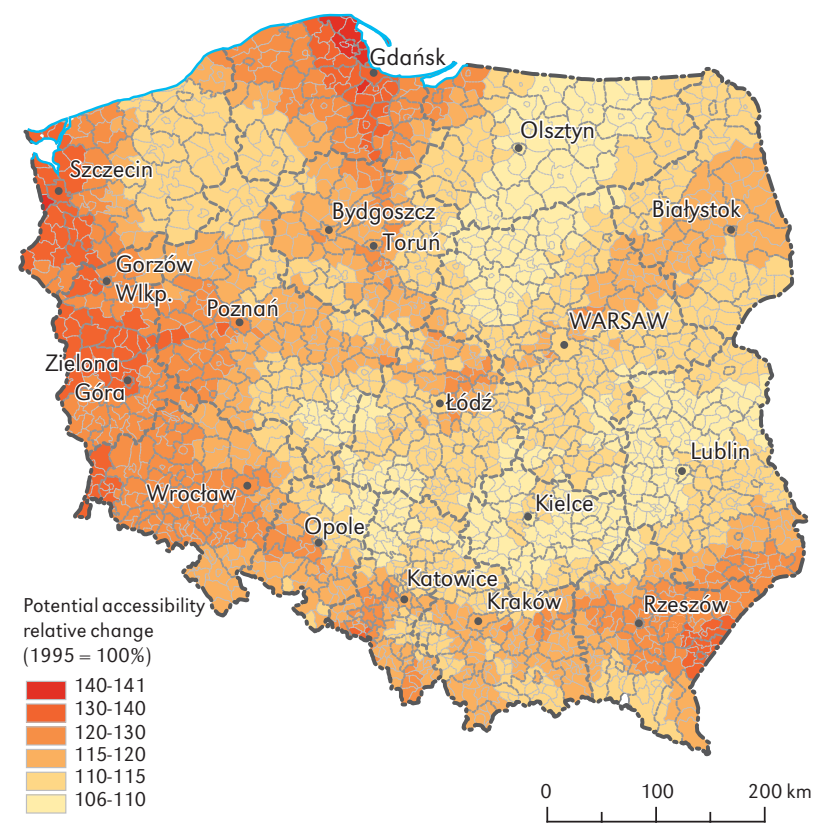

Figure 4. Potential road accessibility changes (1995-2015; relative terms; long trips)

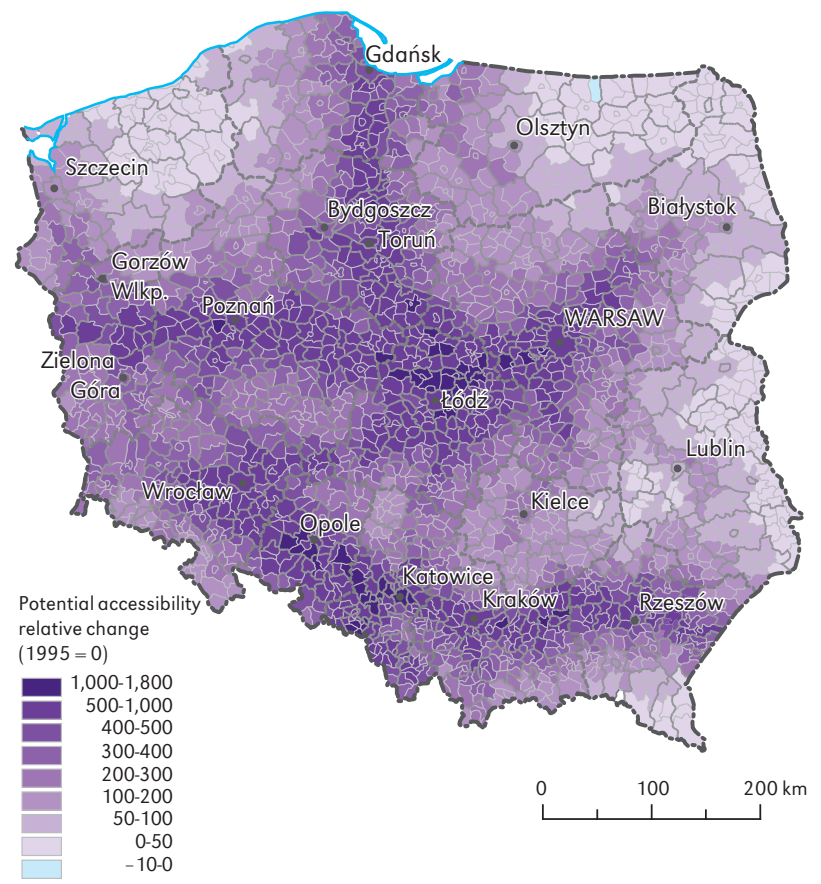

Figure 5. Absolute changes in accessibility level (short trips; 1995-2015) 


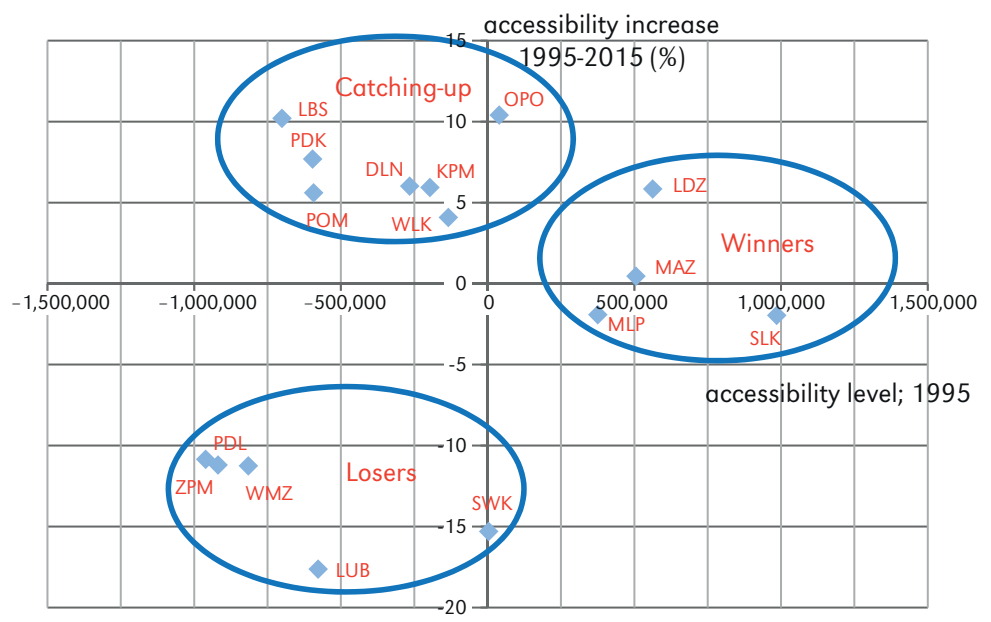

Figure 6. Accessibility beta convergence (1995-2015; short trips)

Voivodship abbreviations: DLN - Dolnoślaskie, KPM - Kujawsko-Pomorskie, LUB - Lubelskie, LBS - Lubuskie, LDZ - Łódzkie, MLP - Małopolskie, MAZ - Mazowieckie, OPO - Opolskie, PDK - Podkarpackie, PDL - Podlaskie, POM - Pomorskie, SLK - Śląskie, SWK - Świętokrzyskie, WMZ - Warmińsko-Mazurskie, WLK - Wielkopolskie, ZPM - Zachodniopomorskie

Małopolskie voivodeships. In the case of Śląskie and Małopolskie, the accessibility improvement is actually somewhat below the national average, but they can also be included in the 'winners' category given that their accessibility base level in 1995 was already high. The most major beneficiaries are therefore the adjacent Łódzkie and Mazowieckie voivodeships (i.e. the central regions including and surrounding Łódź and Warsaw). The transformation process in both its demographic and infrastructural dimensions can thus be said to have stimulated an increase in potential accessibility in central Poland (in particular in the period 2010-2015, when the central parts of the A1 and A2 motorways were being finished).

In the group of 'losers' there are four voivodeships of Eastern Poland plus Western Pomerania (Zachodniopomorskie Voivodeship). Lubelskie (Lublin) Voivodeship is the most major loser, due to the lack of infrastructure investments (save the $\mathbf{S} 17$ express road section between Kurów and Piaski), as coupled with demographic losses. Thanks to the construction of the A4 motorway to the
Polish-Ukrainian border, Podkarpackie is the only voivodeship in Eastern Poland included within the 'catching-up' group.

The cohesion process can also be described by reference to a coefficient of variation obtained when the standard deviation for the accessibility of 2321 Polish municipalities is divided by the average accessibility value in a particular year. If the coefficient of variation is decreasing, this means that accessibility sigma convergence is occurring, while accessibility differences are being reduced. If the coefficient increases - a polarisation process is occurring, with growing regional disparities (Fig. 7).

In the years 1995-2005, a time with relatively few infrastructure investments, the coefficient of variation and regional accessibility disparities increased. However, a consequence of the construction of the S3 and northern sections of the $A 1$ in the years 2005-2010 was the reduction in accessibility disparities. However, the acceleration of the investment process in the years 2010-2015 again led to further divergence. 


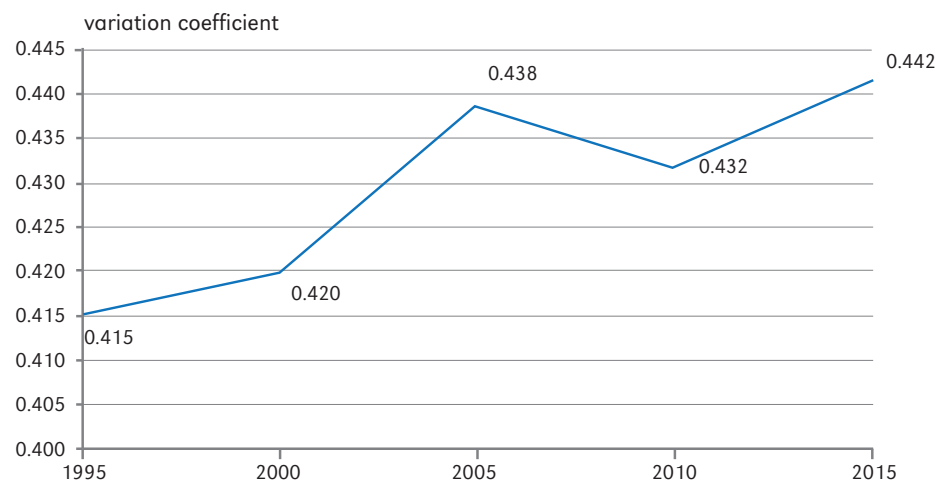

Figure 7. Accessibility sigma convergence (the value of the coefficient of variation)

The process of road-network development in Poland has proceeded via two stages. In the first of these, network expansion is taking place in areas with the greatest traffic volume, mostly the central regions. These areas are characterised by higher-than-average accessibility values, due to their central location. Thus, in the first stage of road-network development, interregional accessibility inequalities are increasing. In Poland, the culmination of interregional differentiation was reached in the 2010-2015 period. This reflects the fact that priority investments (i.e. the A2 Łódź - Warsaw motorway in particular), which should have been implemented at the very beginning of infrastructure development (in the 90s), were postponed. This policy mistake in the implementation of the investment process results in a temporal extension of the first phase of infrastructure development, which will be completed around 2015 .

\section{Spatial scale}

Spatial scale is a key dimension of accessibility. The opening up of the potential model to include the European continent, i.e. by including destinations not only in Poland, but also across the whole of Europe, changes the accessibility pattern within Poland. We assume that, the closer to the border units are, the more they contribute to the accessibility potential of the study area. Therefore, the units on the opposite site of the Polish border are LAU-1 or rayons (units in Russia, Belarus and Ukraine), the further located NUTS-3, NUTS-2 regions or oblasts and the outermost continental EU states constitute separate transport units. After Rosik (2012), the analysis takes into account:

- population changes in 212 transport zones across the European continent (according to Eurostat data and including a forecast to 2015),

- changes in waiting times at Polish borders.

In order to calculate the international (European) accessibility, a number of simplifying assumptions concerning waiting times have been made. It was assumed that in 1995 the waiting time at the border with Germany, the Czech Republic, Slovakia and Lithuania was 30 minutes, and on the eastern border, i.e. on the border with Russia, Belarus and Ukraine, that it was relatively longer and took 60 minutes. In 2007 Poland joined the Schengen zone. Therefore, in 2015, the waiting times at the borders between Poland and neighbouring countries which are in the Schengen zone, i.e. Germany, the Czech Republic, Slovakia and Lithuania, are zero, due to the abandonment of border controls. On the eastern border (i.e. that with Russia, Belarus and Ukraine), new border crossing points opened during the 20 years analysed. However, the eastern border became the external border of the Schengen area and the control there is now much more detailed than 
before. For these reasons, it was assumed that the waiting time at the eastern border in both 1995 and 2015 amounted to 1 hour for each trip performed in this section of the border.

The opening up of the potential model to the entire European continent changes the image of accessibility within Poland significantly. For shorter trips the areas situated along the German border gain, mainly owing to the proximity of Berlin; yet the highest accessibility still characterises Warsaw and Upper Silesia. In addition, the Kraków-Upper Silesia high-accessibility pole seems even to be strengthened by the proximity of Ostrava, and the densely populated region of north-eastern Czech Republic.

Where longer trips are concerned, the highest accessibility is found in Lower Silesia, as well as in the areas bordering with Germany and the Czech Republic. Valuesdecrease in a north-easterly direction. The opening up of the model to the international dimension allows the residents of central Poland to travel quickly to Germany and other countries in western Europe, and results in a major improvement in accessibility over a large area of the Wielkopolskie, Łódzkie and Mazowieckie regions, and a large part of Podlasie or Podlachia, which is an effect of the infrastructure investments in the A2 motorway and $\$ 8$ expressway. The accessibility also improves significantly in a northerly direction in Kujawsko-Pomorskie and Pomorskie voivodeships (thanks to the positive impact of the A1 motorway). The second area of beneficiaries is located along the new central and eastern sections of the A4 motorway, from Opolskie Voivodeship, through Górnoślaskie (Upper Silesia) and Małopolskie, to Podkarpackie. The new sections of the A4 motorway allow the inhabitants of southern Poland to travel comfortably to western and southern European countries (Fig. 8).

\section{Conclusions}

We made several points that summarised our findings in terms of research methods, and dimensions to accessibility. Firstly, potential

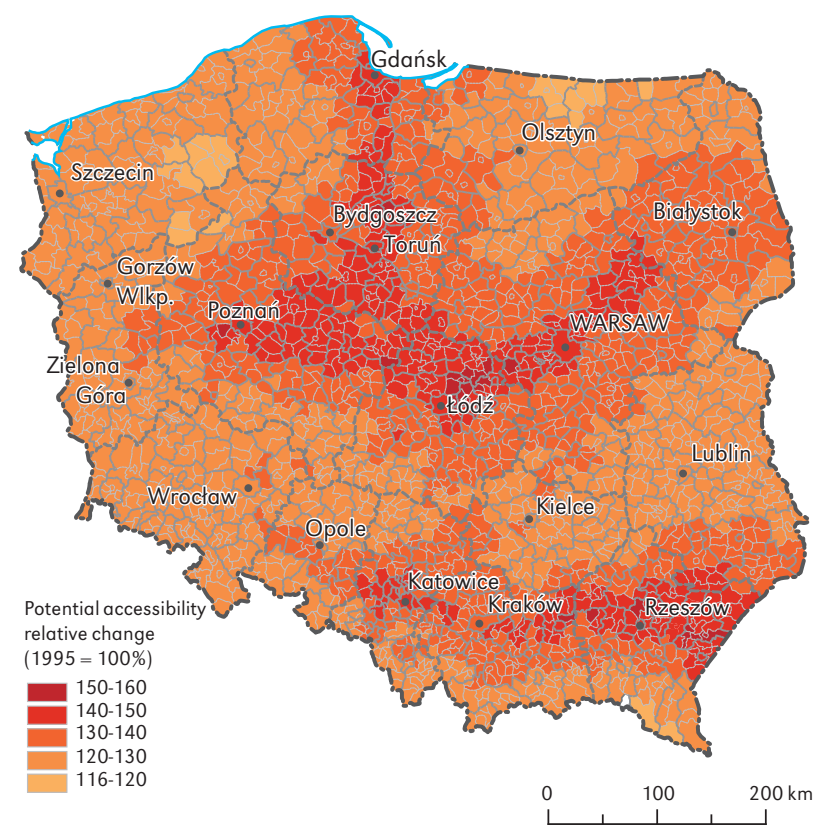

Figure 8. Potential international road accessibility changes (1995-2015; relative terms; long trips) 
accessibility is just one of a range of available methods, such as state of the infrastructure, distance (whether measured in kilometres, time or monetary cost) to one or to a set of destinations, cumulative accessibility measured by estimating what destinations are accessible within a certain time, cost or effort required, accessibility measured in time and space geography or by maximisation of usability. Secondly, the potential accessibility model has strong advantages for practical applications in Poland, with its infrastructural gap, and therefore offers great evaluation potential. Thirdly, potential accessibility offers a broad spectrum of options for analysis, depending on the kind of accessibility dimensions adopted, i.e. unit mass, aggregation of spatial units, the space resistance function and its parameters, geographical coverage of the study, the way in which own potential is taken account of, the mode of transport (passenger or cargo), network topology and the absolute or relative dynamics of the phenomenon. Fourthly, the key dimensions of potential accessibility under Polish conditions include: the spatial scale of the study (above all domestic travel, i.e. destinations only within Poland v. the international scale, which also includes foreign destinations) and trip duration (differentiated through the parameterisation of the beta parameter for the distance decay exponential function). The results may differ radically depending on the study variant chosen.

One of the main conclusions is that in the years 1995-2015, regional disparities in accessibility levels have increased. However, the improvement in accessibility has been distributed unevenly across the country, with the regions in central and southern parts of Poland emerging as the greatest beneficiaries. The only exception is the period 20052010, when the completion of significant new developments in northern Poland led to a relatively faster improvement in the accessibility of peripheral regions than central ones, with sigma accessibility convergence taking place. The demographic factor, including the depopulation process in peripheral areas and the suburbanisation process in most Polish metropolises, was to some extent important in accounting for changes in accessibility level in the years 1995-2005., In contrast, after 2005, it is the infrastructure factor that dominates.

The inclusion of different accessibility dimensions constitutes, in the applied perspective, a premise for planning decisions and the setting of priorities as regards investment projects in road transport. The need to perform simultaneous analyses of domestic accessibility and accessibility in the European dimension (under various variants including different trip lengths and analysis in absolute/relative terms) is indicated, in order that the evaluation of particular sections or programmes (both ex post and ex ante) might also take account of a broader context, in the form of spatial spillovers or network effects.

\section{Acknowledgements}

The results of the analysis presented in this paper use the potential formula developed in the research project entitled "Potential accessibility of regions and their development potential in a 'united' Europe - spatial coverage, length of travel and the border effect (EU-ROAD-ACC)". The research was funded by the National Science Centre allocated on the basis of decision no. DEC-2014/13/B/ HS4/03397". The travel speed model and the road network layer have been prepared under the research project entitled "Complex modelling of road traffic in Poland with the identification of local socio-economic determinants". The research was funded by the National Science Centre, as allocated on the basis of decision no. DEC-2012/05/B/ HS4/04147.

Editors' note:

Unless otherwise stated, the sources of tables and figures are the authors', on the basis of their own research. 


\section{References}

BRUINSMA F.R., RietVelD P., 1998. The accessibility of European cities: Theoretical framework and comparison of approaches. Environment and Planning, 30, 3, 499-521.

CHOJNICKI Z., 1966. Zastosowanie modeli grawitacji i potencjału $w$ badaniach przestrzenno-ekonomicznych. Studia KPZK PAN, 14, Warszawa: Komitet Przestrzennego Zagospodarowania PAN.

CzYŻ T., 2002. Application of the potential model to the analysis of regional differences in Poland. Geographia Polonica, vol. 75, no. 1, pp. 13-24.

Geurs K.T., van EcK J.R., 2001. Accessibility measures: Review and applications. Rijksinstituut voor Volksgezondheid en Milieu report 408505 006, Bilthoven: National Institute of Public Health and the Environment.

GutiérRez J., 2001. Location, economic potential and daily accessibility: An analysis of the accessibility impact of the highspeed line MadridBarcelona-French border. Journal of Transport Geography, vol. 9, no. 4, pp. 229-242.

Guzik R., 2003. Przestrzenna dostępność szkolnictwa ponadpodstawowego w województwie małopolskim. Kraków: Instytut Geografii i Gospodarki Przestrzennego Uniwersytetu Jagiellońskiego.

Hansen W.G., 1959. How accessibility shapes land-use. Journal of the American Institute of Planners, vol. 25, no. 2, pp. 73-76.

Holl A., 2007. Twenty years of accessibility improvements. The case of the Spanish motorway building programme. Journal of Transport Geography, vol. 15, no. 4, pp. 286-297.

IGNRAM D.R., 1971. The concept of accessibility: A search for an operational form. Regional Studies, vol. 5, no. 2, pp. 101-107.

Keeble D., Owens P.L., Thompson C., 1982. Regional accessibility and economic potential in the European Community. Regional Studies, vol. 16, no. 6, pp. 419-432.

Komornicki T., ŚLeszyński P., Rosik P., PomianowSKI W., 2010. Dostępność przestrzenna jako przesłanka kształtowania polskiej polityki transportowej. Biuletyn KPZK PAN, 241, Warszawa: Komitet Przestrzennego Zagospodarowania Kraju PAN.

KoźlaK A., 2012. Dostępność transportowa a mobilność przestrzenna na rynku pracy w województwie pomorskim [in:] P. Rosik,
R. Wiśniewski (eds.), Dostępność i mobilność w przestrzeni. Warszawa: Instytut Geografii i Przestrzennego Zagospodarowania PAN, Ministerstwo Rozwoju Regionalnego, pp. 119-128.

Michniak D., WięCKowski M., StępnIAK M., Rosik P., 2015. The impact of selected planned motorways and expressways on the potential accessibility of the Polish-Slovak borderland with respect to tourism development. Moravian Geographical Reports, vol. 23, no. 1, pp. 13-20.

Potrykowski M., TAYLOR Z., 1982. Geografia transportu: Zarys problemów, modeli i metod badawczych. Warszawa: Państwowe Wydawnictwo Naukowe.

RatajczaK W., 1992. Dostępność komunikacyjna miast wojewódzkich Polski w latach 1948-1988 [in:] Z. Chojnicki, T. Czyż (eds.), Współczesne problemy geografii społeczno-ekonomicznej Polski. Poznań: Wydawnictwo Naukowe UAM, pp. 173-203.

RatAJCZAK W., 1999. Modelowanie sieci transportowych. Poznań: Bogucki Wydawnictwo Naukowe.

Rosik P., 2012. Dostępność lądowa przestrzeni Polski w wymiarze europejskim. Prace Geograficzne, 233, Warszawa: Instytut Geografii i Przestrzennego Zagospodarowania PAN.

Rosik P., Stępniak M., Komornicki T., 2015. The decade of the big push to roads in Poland: Impact on improvement in accessibility and territorial cohesion from a policy perspective. Transport Policy, vol. 37, pp. 134-146.

Schürmann C., Spiekermann K., Wegener M., 1997. Accessibility indicators: Model and report. SASI Deliverable D5, Report to the European Commission, Dortmund: Institute für Raumplanung. Universität Dortmund.

Schürmann C., TalaAt A., 2000. Towards a European peripherality index. Final report. Report for General Directorate XVI Regional Policy of the European Commission, Berichte aus dem Institut für Raumplanung, 53, Dortmund: Universitat Dortmund. Institut fur Raumplanung.

Spiekermann K., Neubauer J., 2002. European accessibility and peripherality: Concepts, models and indicators. Stockholm: Nordregio.

StępNiak M., Rosik P., 2013. Accessibility improvement, territorial cohesion and spillovers: A multidimensional evaluation of two motorway sections in Poland. Journal of Transport Geography, vol. 31, no. 2, pp. 154-163. 
Stępniak M., Rosik P., Komornicki T., 2013. Accessibility patterns: Poland case study. Europa XXI, vol. 24, pp. 77-93.

ŚleszYŃSKI P., 2014. Dostępność czasowa i jej zastosowania. Przegląd Geograficzny, vol. 86, no. 2, pp. 171-215.

ŚLESZYŃSKI P., 2015. Expected traffic speed in Poland using Corine land cover, SRTM-3 and detailed population places data. Journal of Maps, vol. 11, no. 2, pp. 245-254.

TAYLOR Z., 1999. Przestrzenna dostępność miejsc zatrudnienia, kształcenia i usług a codzienna ruchliwość ludności wiejskiej. Prace Geograficzne, 171, Warszawa: Instytut Geografii i Przestrzennego Zagospodarowania PAN.
VICKERMAN R.W., 1974. Accessibility, attraction, and potential: A review of some concepts and their use in determining mobility. Environment and Planning A, vol. 6, no. 6, pp. 675-691.

WięCKOWSKI M., MichniaK D., BednareKSzczepańska M., Chrenka B., Ira V., Komornicki T., Rosik P., Stepniak M., Székely $V_{\text {., }}$ ŚlesZYÝSKI P., ŚWIAৃTEK D., WIŚNIEWSKI R., 2014. Road accessibility to tourist destinations of the Polish-Slovak borderland: 2010-2030 prediction and planning. Geographia Polonica, vol. 87, no. 1, pp. 5-26.

WIŚNIEWSKI S., 2015, Zmiany dostępności miast województwa tódzkiego $w$ transporcie indywidualnym w latach 2013-2015. Przegląd Geograficzny, vol. 87, no. 2, pp. 321-341. 